Dokuz Eylül Üniversitesi-Mühendislik Fakültesi

Fen ve Mühendislik Dergisi

Cilt 20, Sayı 59, Mayıs, 2018
Dokuz Eylul University-Faculty of Engineering Journal of Science and Engineering Volume 20, Issue 59, May, 2018

DOI: $10.21205 /$ deufmd. 2018205953

\title{
Kireçtaşı ve Kumtaşı Rezervuarlarına Sondajı Gerçekleştirilen Orta Doğu Kuyularında Takım Sıkışmaları
}

\section{Tuna EREN ${ }^{*} 1$}

1'̇zmir Katip Çelebi Üniversitesi, Mühendislik Mimarlık Fakültesi, Petrol ve Doğal Gaz Mühendisliği Bölümü, 35620, İzmir. (ORCID: 0000-0003-1258-9230)

(Alınış / Received: 06.02.2018, Kabul / Accepted: 26.03.2018, Online Yayınlanma / Published Online: 15.05.2018)

Anahtar Kelimeler Takım sıkışması, sondör, sondaj mühendisi, sondaj parametreleri, edinilen öğretiler, petrol mühendisliği
Özet: Ham petrol ve doğal gaz kaynaklarına sondaj işlemi kolay bir çalışma değildir ve dikkatli planlama, ve bir problem ile karşılaşıldığında gereken neyse derhal uygulanmasının gerektiği bir çalışmadır. Eğer edinilen öğretiler doğru olarak uygulanmazsa bazı durumlarda takım sıkışmasının yer bulmaması olanak dışıdır. Takım sıkışma olayları karşılaşıldıkları zamanlarsa özellikle denizel ortamlardaki sondaj faaliyetleri kapsamında çok maliyetli ve zaman alan olgulardır. Differansiyel ve mekanik sıkışma olgularına örnekler elde edilen öğretiler ışığında incelenmişlerdir. Yapılan analizler takım sıkışmalarının kuyu içindeki yıkılmalara ve yüksek geçirgenlikli formasyonların sondajlarının yapılmakta olğundan karşılaşılmış olduğuna işaret etmektedir. Sondaj esnasında takım sıkışmasına dayanan genel riskler hasarlı zayıf kalitede olan ihtiyaç duyulan niteliklerde standartlara sahip olmayan kuyu çeşitleri ile sınırlı değildir. Sondaj tarihinde sınırsız sayıda takım sıkışması ile karşılaşılmıştır ve büyük boyutlarda zaman ve maddi kayıp yer bulmuştur, cevaplanması gereken soru ise endüstrinin geçmiş davranışlardan edinilen öğretileri öğrenmiş olup olmadığıdır. $\mathrm{Bu}$ çalışma takım sıkışmalarının oluşumlarının engellenmesinin en güçlü yollarının takımın sıkıșmış olması durumunda güçlü bir sondaj planlamasıyla birlikte edinilen öğretilerin uygulanması olduğunu ortaya çıkarmaktadır.

\section{Stuck Pipe Incidents in Middle East Wells Drilled to Limestone and Sandstone Reservoirs}

Keywords
stuck pipe, driller,
drilling engineer,
drilling
parameters,
lessons learned,
petroleum
engineering

Keywords

stuck pipe, driller, drilling engineer, drilling lessons learned engineering

\begin{abstract}
Drilling for natural gas and oil resources is not an easy task, and requires careful planning, and instant implementation of necessary actions when a trouble is faced. The occurrence of stuck pipe incidents are inevitable in some occasions if lessons are not correctly implemented. The stuck pipe incidents when encountered especially in offshore wells while drilling operations are very costly and time consuming. Examples of differential and mechanical stuck incidents are examined together with the
\end{abstract}


respective lessons learned. Analyses indicate that stuck pipe incidents are due to the sloughing within the wellbore, and drilling across highly permeable shale formations. Common risks to be encountered during drilling due to the stuck pipe occurrences are not limited to having a damaged poor quality well that is not designed up to the required needs. In history of drilling numerous stuck pipe events have occurred, with considerable amount of time and money loss, the question now is to see whether the industry has learned from its past behaviours? Study reveals that the most powerful ways to prevent occurrence of stuck incidents is implementing the lessons learned in case of getting stuck with a sound drilling plan already in place.

\footnotetext{
*Sorumlu yazar: tuna.eren@ikc.edu.tr
}

\section{Introduction}

Stuck pipe occurrences are instances not desired to be encountered in drilling operations. However they are not inevitable. Stuck pipe events have been encountered in the past; and are going to be encountered in the upcoming drilling campaigns. The most important key to prevent occurrences of stuck pipe events is having a good well drilling plan. The second significant key is to ensure that the plan is implemented as needful. The two most important individuals in drilling operations to prevent the stuck pipe events are the planner (usually the drilling engineer) and the driller. Driller is the rig staff who is in charge of commanding the rig unit and the drillstring. The drilling engineer should ensure in his calculations that the parameters to be implemented are not going to be creating any problems, and the driller is going to ascertain that the planned parameters are correctly being exercised. Each and every segment of the hole is required to be adequately understood so that possible risky zones are treated cautiously especially while tripping in and out of the possible trouble zones.

One of the very reasons of getting mechanically stuck is due to inadequate or improper hole cleaning. Pumping at a flow rate that is more than necessary would not certainly prevent stuck pipe occurrences on the contrary it can lead to a damaged wellbore and a subsequent stuck pipe occurrence.

The most recent wells in contrary to the initial days of drilling campaigns are being drilled deviated rather than being vertical. The deviation in the wells comes with more considerations; such as the additional bends, increased risk of getting differentially stuck when the drillsting would be laying immediately above the depleted permeable formations.

This study is analysing the field cases for stuck pipe events and giving the details of lessons learned and how they shall be implemented so that the lost time incidents during the drilling operations are not encountered. The observations carried out in the field operations indicate that stuck pipe incidents can be prevented provided that the previous errors are not repeated. The findings out of this study bring together the significant lessons learned.

\section{Literature Review}

Many researchers worked on the root causes of stuck pipe occurrences. Operators and Contractors published their own stuck pipe prevention methodologies and ways to handle them. However stuck pipe instances are still happening. An example to a stuck pipe event from the study of $\mathrm{Al}$-Saeedi et al. 
[1]; is from a high angle well drilled up to 29 degrees in Kuwait in which the string is reported to have been stuck in a deep depleted formation. The string was freed and the drill collars which had sticking tendency were replaced with Heawy Weight Drillpipes. Aadnoy et al. [2] in their research stated that the main conclusions for stuck pipe events is that the most important element to free the string is to keep the bottom-hole pressure as low as possible.

Sun and Gao [3] stated that hole friction, tool joint, upset end of drill pipe, tubular sizes and materials have significant effects on the pull length and/or the twist angle of the stuck drill string. Their study introduced a new method in response to the type of wells such as extended reach wells, in terms of introducing a numerical method taking into account downhole friction, tool joints, upset end of drillpies, tubular materials and sizes to determine the stuck point in extended reach wells.

Eren et al. [5] stated that stuck pipe events are evitable with continuous efforts including conducting meetings with crew prior to the commencements of the shifts, studying the offset wells in detail, understand sticking mechanisms, and taking the actual stuck-pipe events as lessons learnt. Their study revealed the importance of the crew and drillers role in understanding the indications being given by the well.

Shahbazi and Shahri [6] reported that stuck pipe incidents were proportional to the mud weight, initial gel strength, yield point, solid content, and temperature, and is also an inverse of plastic viscosity, march funnel viscosity, and dial reading at $600 \mathrm{rpm}$ to the power of 0.3. Monitoring the stuck pipe tendency helps driller to know whether the drilling process results in stuck pipe or not.
The present industry standard is to ensure that $100 \mathrm{klbs}$ of overpull is always available. The nature of the stuck incidents from time to time necessitate overpull magnitudes of more than 100 klbs in most stuck events. The stuck pipe events are preventable if the filter cake of the mud is thin and impermeable, filtercakes otherwise could be damaging in addition to the sticky behaviour which may cause differential stuck pipe events. Other two main groups of stuck pipe events are Solids Induced Packs Offs and Wellbore Geometry Related stuck pipe events. Figure 1 gives the mechanisms of pipe sticking.

The presented stuck pipe mechanism occurences in Figure 1; are categorised in three different main sub groups. Solids related packoffs are known to be ecountered mainly due to inadequate hole cleaning, over pressured shales and unconsolidated formations. Reactive formations (such as shale formations) is the most common among all. The secon sub group is the well geometry related stuck events. Doglegs and ledges are the main sources of problems being encountered. Nowadays the drilling of deviated and horizontal wells are increasing in number and therefore the stuck events related to well gometry should also include stuck events related with the wellbore trajectory. The last sub group is the stuck events related to differential sticking. High overbalances across the deplted formations, and inadequate filter cake issues are the main driving sources for the differential sticking issues in wellbores.

Yarim et al. [7] observed that the majority of the training material available in the industry is providing information on how to free the stuck pipe, rather than on how to prevent the occurrence of the incidents. This is a draw back by the industry and addresses to the point that how important it is to 
equip the field personnel with the right tools to interpret and listen to the ongoings in a well.

DeGeare [8] stated that pipe can become stuck during drilling and workover operations even when preventive measures are taken. When pipe sticking occurs, special tools and expertise are required to avoid expensive, time consuming, trial and error fishing operations. Applying lessons learned by personnel on many previous jobs to the planning and taking the advantage of the latest advances in tools and techniques will maximize the ability in overcoming challenges successfully.
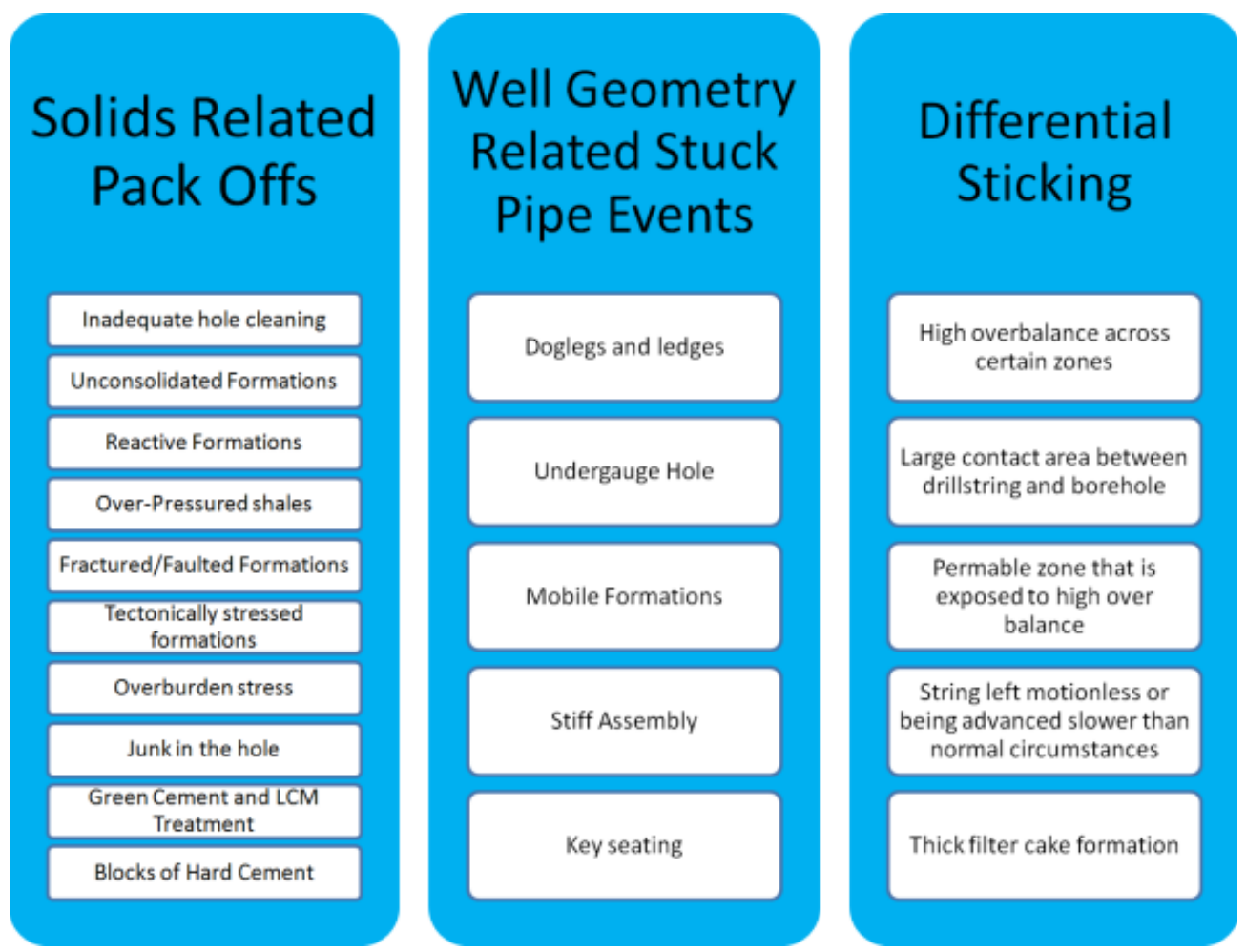

Figure 1. The mechanism of stuck pipe occurrences

3. Field Case Examples to Stuck Events The data given for the field cases are collected from drilling campaigns conducted in the Middle East Geomarket. The stuck incidents are analysed together with BHA (Bottom Hole Assembly), and drilling parameters summary. The Lithology of the Southern Iraq Oil Fields are similar to that of the given in Figure 2, after Al-Saeedi et al. [3], in which the stratigraphic/lithology of Kuwait is highlighted giving the troublesome formations.
The main drilling problems known to be encountered in the area are not limited to the Major Loss Zones such as in Dammam and Hartha Formations, Sulphurous water from Tayarat/Radhuma Formations, and Wellbore Instability problems in Burgan Formation. Three stuck pipe incidents are analysed in the scope of this study.

Most of the stuck pipe problems occurred in the analysed oil field(s) in Middle East Geomarket occurred due to marl and sloughing shales, together with excessive 
drilling fluid density in borehole which resulted in stuck pipe incidents. The representative PPFG (Pore Pressure Fracture Gradient) chart belonging to the Southern Oil Fields in Iraq is given in Figure 3. The data points in the PPFG chart are the actually measured formation test results. In the field rightt after the setting of the casing, a formation strength test is conducted. The results of the test reveal at what surface pressure the formation leak off is going to occur.

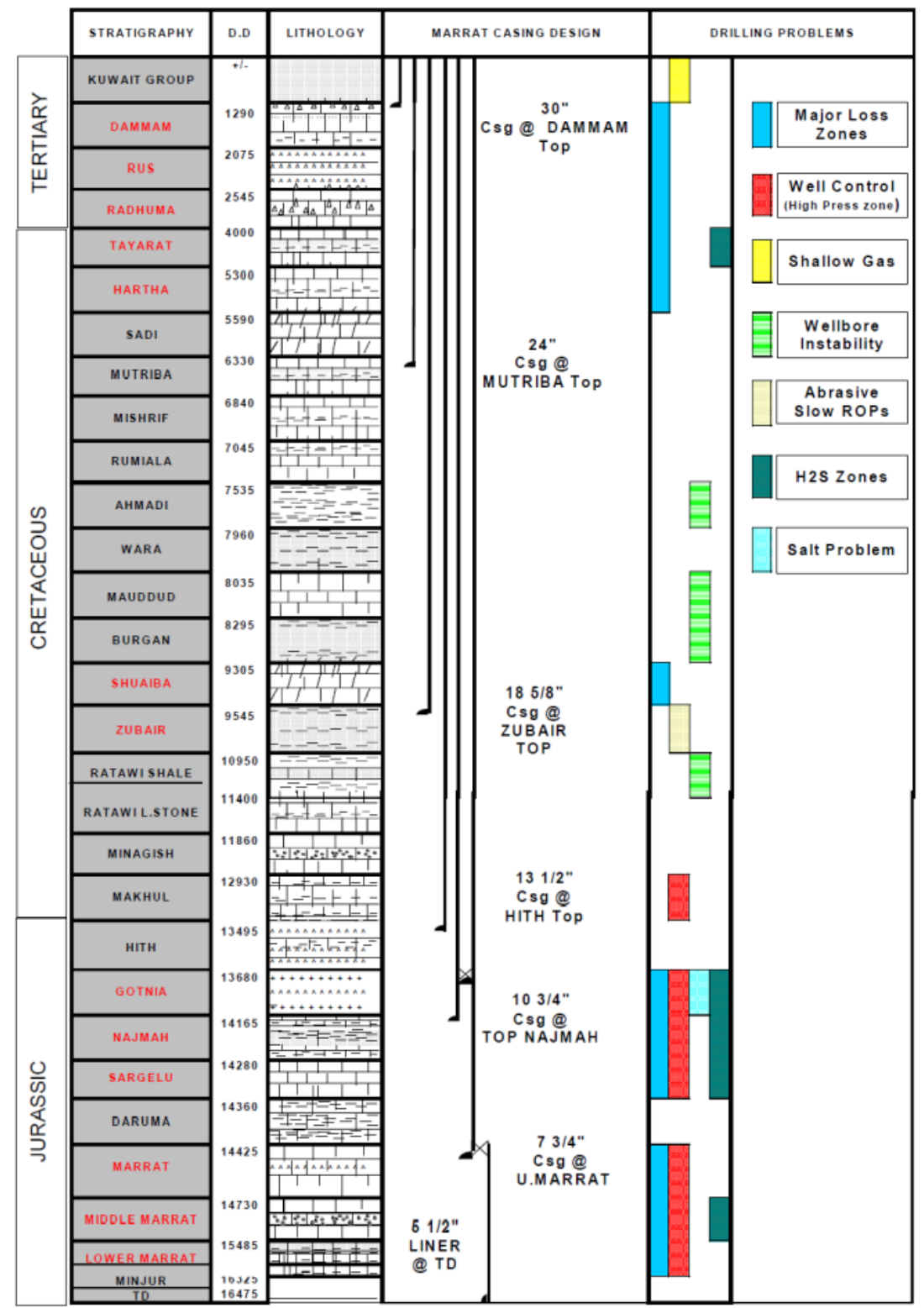

Figure 2. Lithology and Drilling Problems in Middle East, after Al-Saeedi et al. [3]. 
T. Eren / Stuck Pipe Incidents in Middle East Wells Drilled to Limestone and Sandstone Reservoirs

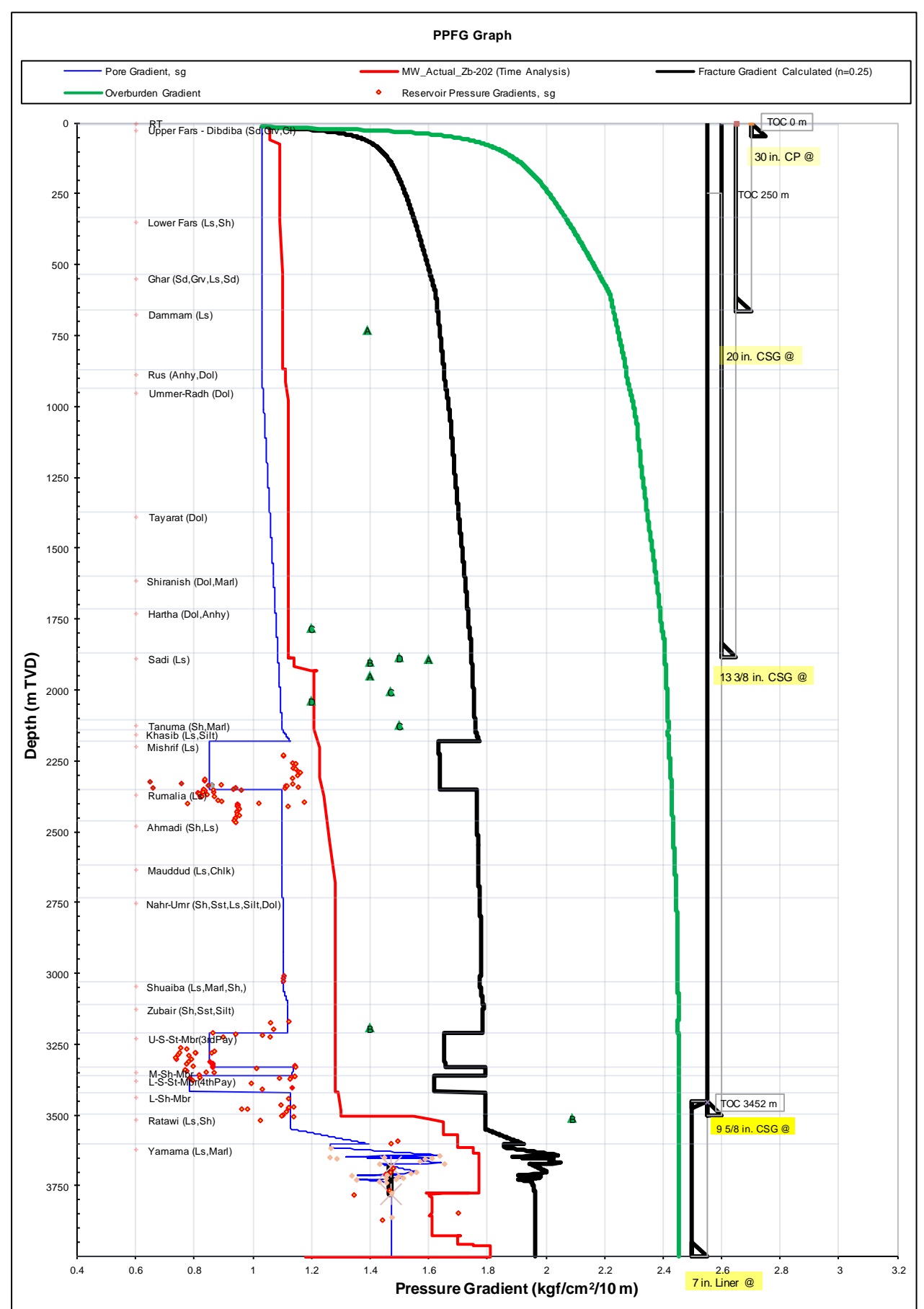

Figure 3. PPFG (Pore Pressure Fracture Gradient) Chart of Southern Iraq, after Eren et al. [5] 
Accurate PPFG charts are very important for the planning requirements of the wells and interventions in case of stuck pipe incidents.

\subsection{Stuck Incident in Well-A}

In Well-A the summary of events are as follows which leaded the drillstring to get stuck. The hole section was $121 / 4 "$ and the depth was at $2235 \mathrm{~m}$. A partial loss circulation was observed and the flow rate was reduced step by step from $3300 \mathrm{lpm}$ down to $2500 \mathrm{lpm}$. Drilled to 2247 m, lost 285 bbl mud. Drilled with $2000 \mathrm{lpm}$ down to the bottom of Mishrif $(2378 \mathrm{~m})$. Increased flow rate to 2400 lpm and drilled ahead to $2453 \mathrm{~m}$, the lost rate ranged between 30 and $50 \mathrm{bbl} / \mathrm{h}$. Circulated the hole and spot $130 \mathrm{bbl} \mathrm{LCM}$ (Lost Circulation Material) pill. $\mathrm{POOH}$ (Pulled Out of Hole) to $2407 \mathrm{~m}$. Attempted to pump out, however SPP (Stand Pipe Pressure) increased to 2500 psi. POOH with 40 tons over pull up to $2265 \mathrm{~m}$. Jarred up and down without success. Lost the flow while back reaming. Workstring stuck at $2265 \mathrm{~m}$.

Figure 4 shows the Well-A stuck incident graphical representation. The BHA is mainly composed of Bit + Mud Motor + Float Sub + String Stabilizers + Drill Collars and a Jar.

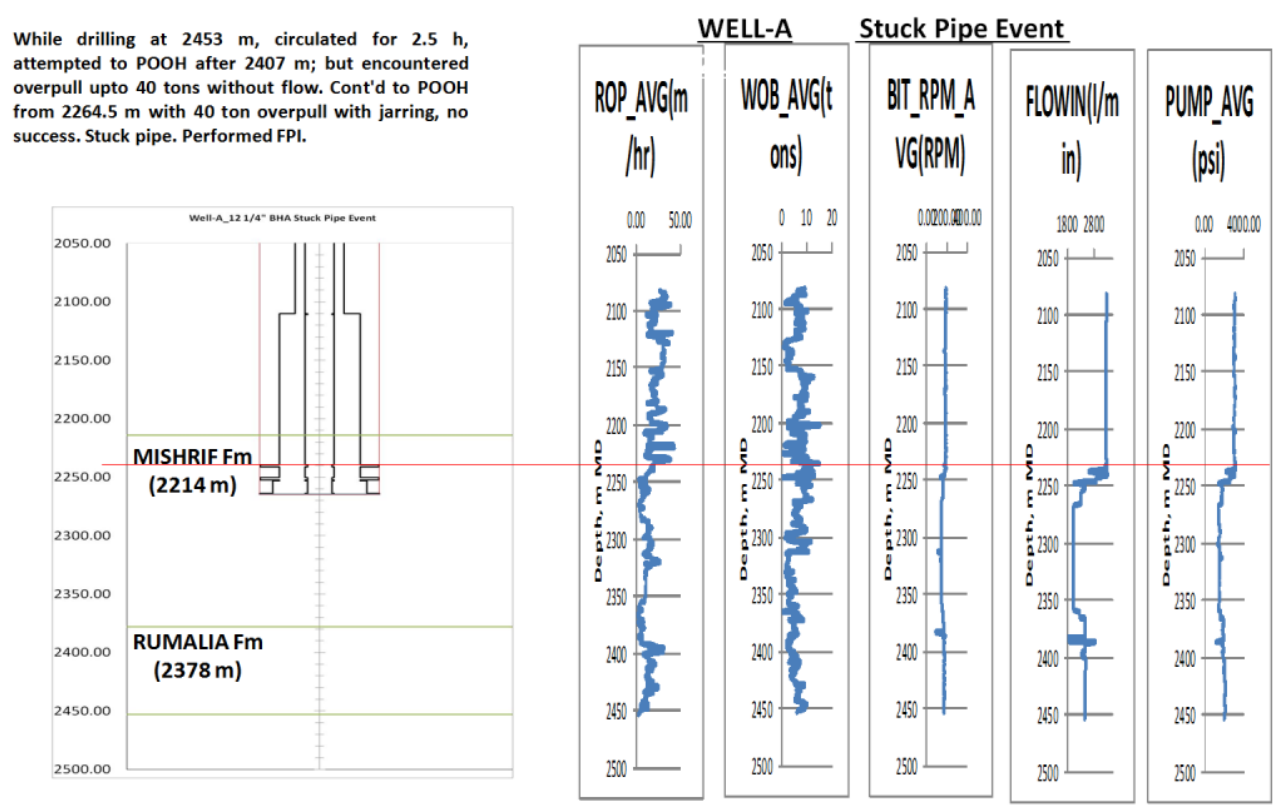

Figure 4. Well-A stuck incident graphical representation after Eren et al. [5]. While drilling at $2453 \mathrm{~m}$, circulated for $2.5 \mathrm{~h}$, attempted to $\mathrm{POOH}$ after $2407 \mathrm{~m}$; but encountered overpull upto 40 tons without flow. Cont'd to POOH from $2264.5 \mathrm{~m}$ with 40 ton overpull with jarring, no success. Stuck pipe. Performed FPI.

The flow rate indicates that it was reduced at the depth of $2235 \mathrm{~m}$, the depth at which losses occurred. The Mishrif Formation is in depletion and loss circulations are expected. It is observed that at the moment of drilling prior to the stuck pipe event; flow rate was at a magnitude that is approximately equal to providing minimum annular velocity. It is important to remember that the 19 hours drilling process (between the 2324-2453 $\mathrm{m}$ interval) continued with partial losses, $20-90 \mathrm{bbl} / \mathrm{h}$.

The calculations reveal that the insufficient flow rate accompanied with relatively high rate of penetration; resulted in accumulation of excessive 
cuttings in the annulus. Even though the bottom up time was 70 mins, and the hole was circulated for two bottoms up, and whenever the string pulled out, the stuck pipe event occurred at the moment the top of the upper stabilizer came in contact with the accumulation of cuttings across the Mishrif Formation. The string was pulled to $2294 \mathrm{~m}$ by 40 ton overpull, beyond the $2268 \mathrm{~m}$ depth the overpull attempts were not successful. The circulation was also lost due to the accumulated cuttings and LCM inside the string and annulus. The stuck pipe incident occurred was reported to be a solids related pack-off with inadequate hole cleaning. The well was sidetracked by means of a back off at $2168 \mathrm{~m}$; following all of the fishing attempts, including acid pumping.

The stuck pipe event that happened in Well-A would have been prevented should more attention had been put in place. Proper hole cleaning practices must have been applied and minimum annular flow rate must have been attained. The circulation prior to the pull out must have been kept longer.

\subsection{Stuck Incident in Well-B-ST-1}

The second stuck pipe is detailed for Well-B. The stuck pipe event that happened in Well-B-ST-1 would have also been prevented should more attention had been put in place and maintenance of the rig machinery not performed while the BHA was across the open hole interval. Figure 5 shows the Well-B-ST-1 stuck incident graphical representation. The BHA for this wellbore is exluding directional tools and mainly formed of Bit + Near Bit Stabilizer + String Stabilizers + Drill Collars and a Jar.

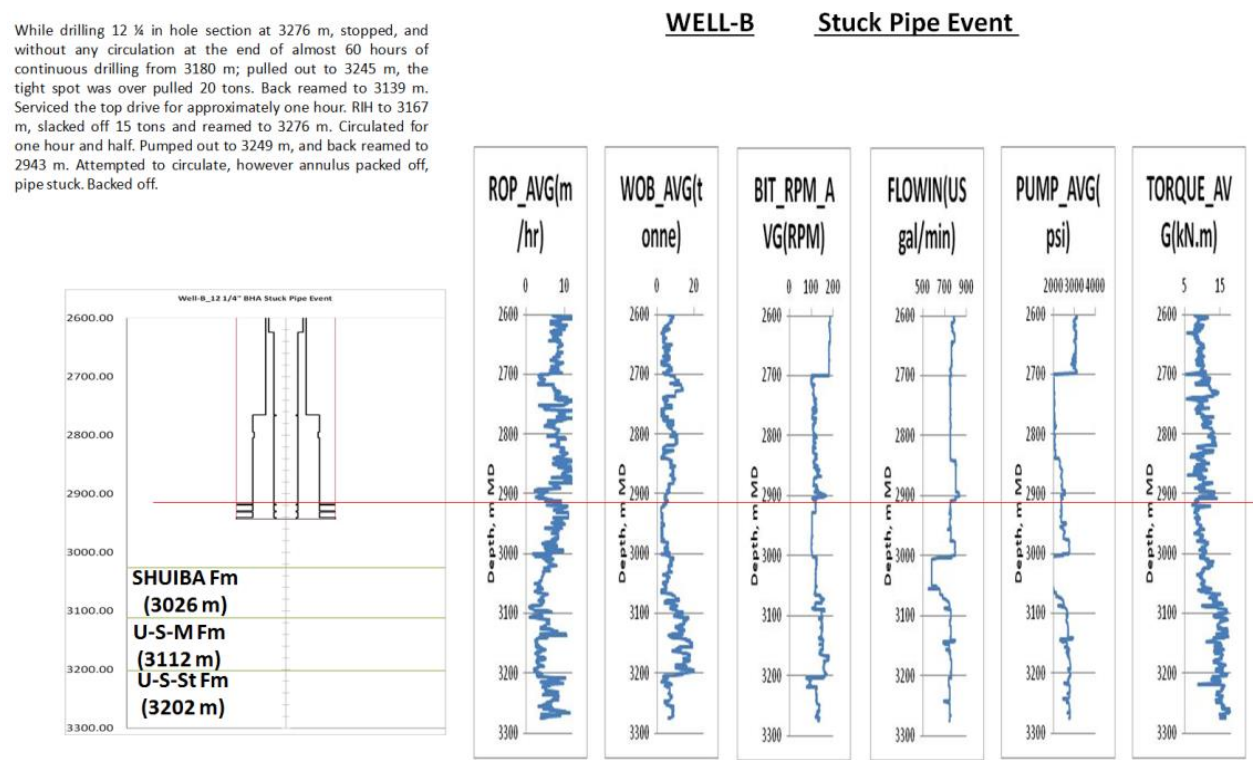

Figure 5. Well-B stuck incident graphical representation after Eren et al. [5]. While drilling 12 $1 / 4$ in hole section at $3276 \mathrm{~m}$, stopped, and without any circulation at the end of almost 60 hours of continuous drilling from $3180 \mathrm{~m}$; pulled out to $3245 \mathrm{~m}$, the tight spot was over pulled 20 tons. Back reamed to $3139 \mathrm{~m}$. Serviced the top drive for approximately one hour. RIH to 3167 $\mathrm{m}$, slacked off 15 tons and reamed to $3276 \mathrm{~m}$. Circulated for one hour and half. Pumped out to $3249 \mathrm{~m}$, and back reamed to $2943 \mathrm{~m}$. Attempted to circulate, however annulus packed off, pipe stuck. Backed off. 
As contrary to the case explained in Well-A, in Well-B the drilling parameters especially the flow rate was rather constant. The stuck pipe had taken place following the long duration of drilling without any pumping of HIVIS pill or adequate circulation at the bottom. The annulus has been filled in with cuttings, and the string having been stopped in the open hole, maintenance of the rig machinery has been performed. The circulation that has been performed for duration of 1.5 hours is observed not to be enough considering the fact that the hole is not in gauge.

The circulation should have been kept longer for at least two bottoms up as per best petroleum industry practices and experience in the Oil Fields of Middle East. The stuck pipe incident occurred was reported to be a solids related packoff with inadequate hole cleaning.

\subsection{Stuck Incident in Well-B-ST-2}

The third stuck pipe is detailed for WellB ST-2. This stuck event is due to the differential sticking mechanism. $\mathrm{h}$

Drilling in the depleted formations, across which the bottom hole hydrostatic pressure exceeds the pore pressure, may result in differential sticking issues. Such troubles are very difficult to free the string when encountered, since the string gets embedded into the filter cake deposited across the low pressure formation. The force to pull the pipe at some occasions could get extremely high. Figure 6 presents the drawing of differential sticking mechanism.

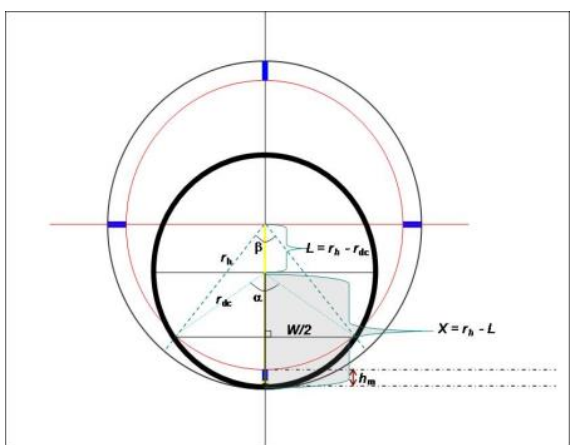

Figure 6. Differential sticking drawing Differential sticking of the drillstring occurs when mud cake is thick enough and the wellbore pressure exceeds the pore pressure.

Mitchel [9] defined the projected width of the contact area as given in equation 1.

$W=2 r_{d c} \sin \left(a \cos \frac{\left(2 r_{h}-2 h_{m}\right)^{2}-\left(2 r_{d c}\right)^{2}-\left(2 r_{h}-2 r_{d c}\right)^{2}}{2\left(2 r_{h}-2 r_{d c}\right) 2 r_{d c}}\right)$

the differential pressure is calculated using equation 2 :

$$
P_{d}=\frac{T}{C L W}
$$

When attempted to pump out of hole, after having circulated for two hours only, noted that the string was differentially stuck at $3775 \mathrm{~m}$. The circulation was performed with a flow rate of $880 \mathrm{lpm}$. However the minimum flow rate must have been at a rate of $1020 \mathrm{lpm}$, which reveals that the hole cleaning was not at the desired rate. The drilling fluid density was reduced from $1.77 \mathrm{sg}$ to $1.74 \mathrm{sg}$ to have less differential pressure across the stuck interval. Attempts to release the string by pulling and slacking off 60 tons did not provide enough pull to free the string. The stuck pipe incident occurred was reported to be a differential sticking in kind with permeable zone 
exposed to high overbalance. Figure 7 shows the Well-B-ST-2 stuck incident graphical representation. The BHA for this wellbore is formed of a coring assembly. The components of the BHA include core barrels with stabilisers,

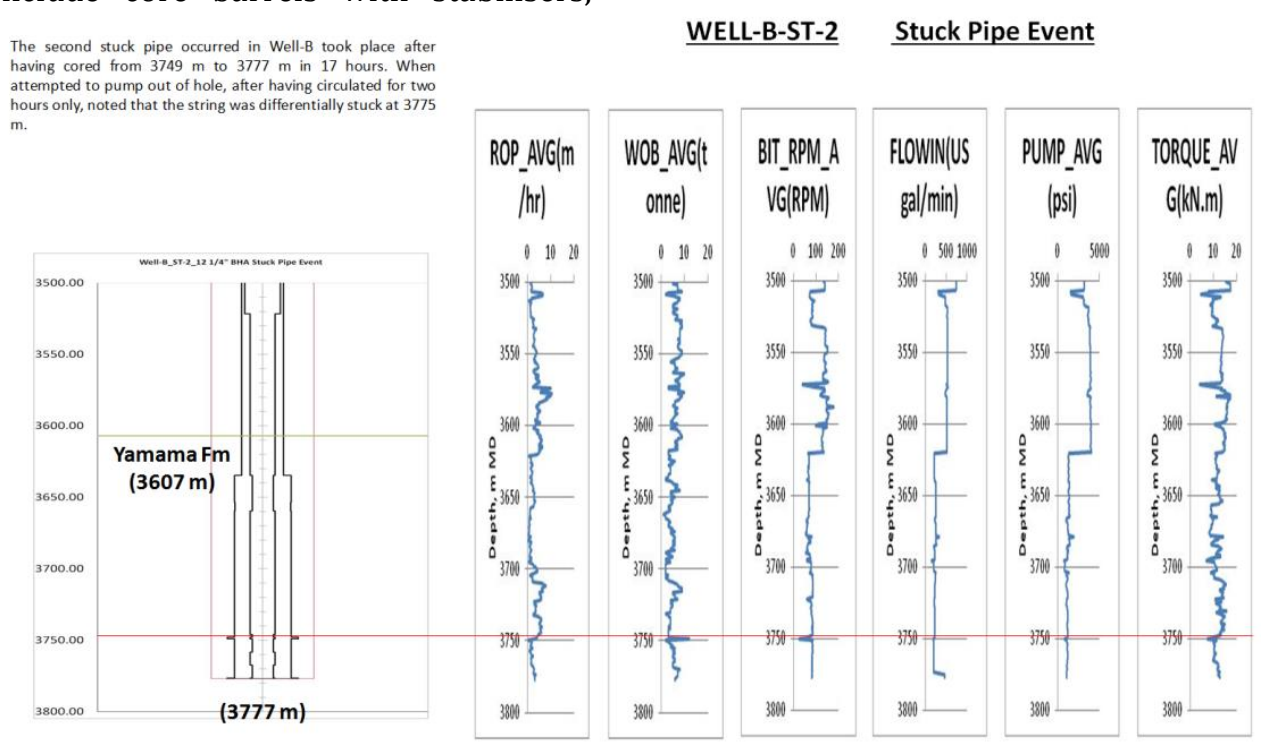

Figure 7. Well-B ST-2 stuck incident graphical representation after Eren et al. [5]. The second stuck pipe occurred in Well-B took place after having cored from $3749 \mathrm{~m}$ to $3777 \mathrm{~m}$ in 17 hours. When attempted to pump out of hole, after having circulated for two hours only, noted that the string was differentially stuck at $3775 \mathrm{~m}$.

The differential sticking mechanism is a complex and requires the very necessary freeing action to get unstuck, since the freeing force could be well over the pull capacity of the drillstring. The area of contact is calculated using the following equation as given by Bourgoyne et. al. [10]:

$A=12 \times 2 h \sqrt{\left(\frac{d_{2}}{2}-h_{m}\right)^{2}-\left(\frac{d_{2}}{2}-h_{m} \frac{d_{2}-h_{m}}{d_{2}-d_{1}}\right)^{2}}$

The force to free a differentially stuckpipe is as given in equation (4):

$F_{s t}=\Delta p A C$
Flot sub, circulating subs, drill collars and a Jar.

\section{WELL-B-ST-2 $\quad$ Stuck Pipe Event}

The calculations revealed that freeing force based on assumed wellbore condition was above the pull rating of the drillstring in use at the time of the stuck. Successive attempts of pumping fluid spots also proved to be unsuccessful. Backed off the string and continued operations performing a sidetrack.

\section{Lessons Learned}

In addition to the lessons learned for the stuck cases given in this manuscript the list of lessons learned from drilling practices in Middle East Geomarket is as given in Table 1. Each and every single item of lessons learned given in this document is based on a real field case encountered in drilling operations. 
Table 1: Lessons Learned from Middle East drilling operations.

\begin{tabular}{ll}
\hline Event & Description \\
\hline & \\
& \\
Differential stuck & $\begin{array}{l}\text { While drilling across a depleted } \\
\text { reservoir formation with a bent- } \\
\text { in a depleted } \\
\text { motor, the string stuck } \\
\text { differentially. }\end{array}$
\end{tabular}

Use of higher grade DP string against being limited to maximum overpull

Circulation at the bottom prior to pulling out of hole

Pumping periodical viscous pills

Prenventing the drillstring being stationary in openhole intervals

Keeping the drillstring for strictly unnecessary reasons is a recipe for a stuck pipe event.

In the wells with circulation loss issues; circulations at the bottom should be long enough to ensure a cleaned annulus.

The pills will be incorporated into the mud system and eventually build up a good rheology. The drilling fluid rheology may be supplemented with addition of polymer to maintain effective holecleaning.

Pumping acid to free a stuck string

\section{Lesson Learned}

Motor BHA strings should be considered as the last option for depleted reservoir sections. Pore pressure/Fracture gradient charts shall be well understood. Detailed response plans shall be readily available so that the driller can refer to in case of urgent requirement.

It is always very important to have a workstring which can handle the maximum overpull requirements in an area to free the string against differentially stuck incidents.

Proper hole cleaning practices must have been applied and minimum annular flow rate must have been attained. The circulation prior to the pull out must have been kept longer.

Periodical High Viscosity pills are suggested to be pumped at regular intervals (e.g. $15 \mathrm{~m}$ or every two hours) to ensure efficient hole cleaning.

While across open hole never keep the workstring stationary, always ensure the string is reciprocating, rotating and circulation in progress if drilling is not continuing.

In the event of stuck pipe across a limestone formation pumping $22 \% \mathrm{HCl} / \mathrm{HF}$ acid to cover the annulus area from the bit the top of the carbonate formation and make sure that the acid pill soaks for duration of two hours while attempting to rotate the string. 


\section{Conclusion}

The implementation of lessons learned out of past events is the key factor in preventing occurrences of stuck pipe events. Previous researches mentioned that most of the stuck pipe events are avoidable with good planning and listening to the response of wellbore whilst drilling. Understanding the details of the wellbore sections is very important in preventing the stuck incidents. The person(s) in charge of the drilling operation shall be feeling in what condition is each and every section of the wellbore. Each stuck incident shall be attempted to be resolved with the correct strategy in initial recovery attempts which shall be developed after having firmly understood what actually caused the drillstring get stuck.

The most significant finding of this study is the importance of hole cleaning, preventing the string being stationary for strictly unnecessary reasons when in open hole. Use of a workstring with the maximum axial rating, and having enough acid concentration readily available whilst drilling operations are other finding of this study to minimize loss of time and efforts against stuck pipe incidents. It should be born in mind that the string shall not be kept stationary in the open hole unless strictly necessary. With this study the presented novel lessons learned if implemented appropriately will definitely contribute to achieving successful drilling campaigns and organizations are going to benefit by saving time and cost.

\section{Nomenclature}

$\mathrm{C}=$ coefficient of friction

$\mathrm{d}_{1}=$ outer diameter of drill collars (in)

$\mathrm{d}_{2}=$ diameter of the borehole (in)

$\mathrm{h}_{\mathrm{f}}=$ thickness of the low pressure, permeable formation (ft)

$\mathrm{h}_{\mathrm{m}}=$ mud cake thickness (in)
$\mathrm{L}=$ Contact length of pipe with the cake (ft)

$\mathrm{P}_{\mathrm{d}}=$ differential pressure (psi)

$\mathrm{r}_{\mathrm{h}}=$ radius of the borehole (in)

$\mathrm{r}_{\mathrm{dc}}=$ radius of the workstring (in)

$\mathrm{T}=$ tension $(\mathrm{klbs})$

$\mathrm{W}=$ projected width of the contact area

(in)

\section{References}

[1] Al-Saeedi, M., Munger, R., Tooms, P., Al-Mutairi, B., Al-Quraini, K., Decaire, J., \& Tuncer, T. 2001. First High Pressure, High Angle Well in Kuwait: Case Study of WMN-2. SPE/IADC Middle East Drilling Technology Conference, 22-24 October, Bahrain. pp.1-13. doi:10.2118/72299-MS

[2] Aadnoy, B. S., Larsen, K., \& Berg, P. C. 2002. Analysis of Stuck Pipe in Deviated Boreholes, Journal of Petroleum Science and Engineering, Volume: 37 Issue: 3-4 pp. 195-212, doi: 10.1016/S09204105(02)00353-4

[3] Sun, Lianzhong, and Deli Gao. 2011. A numerical method for determining the stuck point in extended reach drilling, Petroleum Science, Volume: 8. Issue:3: pp. 345-352, doi: 10.1007/s12182011-0151-z

[3] AL-Saeedi, M., Al-Mutairi, B., ALKhaldy, M., \& Sheeran, T. 2003. Fastest Deep Marrat Well in North Kuwait: Case History of Raudhatain 206. SPE/IADC Middle East Drilling Technology Conference and Exhibition, 20-22 October, $\mathrm{Abu}$ Dhabi, UAE. pp.20-22. doi:10.2118/85287-MS

[5] Eren T., Azeez M., and Tawfeeq B. A. 2013. Stuck Pipe Prevention While Drilling Wells to Limestone \& Sandstone Reservoirs - Southern Iraq. Second International 
T. Eren / Stuck Pipe Incidents in Middle East Wells Drilled to Limestone and Sandstone Reservoirs

Conference on Water, Energy and the Environment, 21-24 September, Kusadasi, pp. 1-8.

[6] Shahbazi, K., Shahri, M.P. 2012. The development of a window for stuck pipe prediction. Petroleum Science and Technology, Volume: 30 , Issue: 2, pp. 176-192, doi: 10.1080/10916461003792302

[7] Yarim, G., Uchytil, R. J., May, R. B., Trejo, A., \& Church, P. 2007. Stuck Pipe Prevention--A Proactive Solution to an Old Problem. SPE Annual Technical Conference and Exhibition, 11-14 November, Anaheim, CA. pp. 1-12. doi:10.2118/109914-MS

[8] DeGeare, Joe P. 2003. The guide to oilwell fishing operations: tools, techniques, and rules of thumb. Gulf Professional Publishing, 210p.

[9] Mitchell. B. 1995. Advanced Oilwell Drilling Engineering Handbook \& Computer Programs. 10th ed. Lakewood, CO: Mitchell Engineering, 605p.

[10] Bourgoyne A.T., Millheim K.K., Chenevert M.E., Young F.S.1986. Applied Drilling Engineering. Society of Petroleum Engineers, 502p. 